\title{
Protected Area Establishment and Its Implications for Local Food Security
}

\author{
Elaine M. Nakamura' and Natalia Hanazaki \\ Department of Ecology and Zoology \\ Universidade Federal de Santa Catarina, Brazil
}

\section{Abstract}

The establishment of protected areas can reduce access to natural resources for communities that depend on such areas for food, and can thus contribute to food insecurity. We studied the local food systems of two communities that surround a protected area in southern coastal Brazil and the relationship between the protected area and local food security. We randomly selected 34 households to perform 24-hour recalls of food intake and administered a questionnaire that addressed food security. Our key findings were: (1) the consumption of biological resources is based on cultivated, raised, and fished food items, which are locally purchased, produced, or caught by households; (2) food vulnerability is related to household income; (3) there is a greater reliance on resources from the protected area among households with livelihoods that depend on the local environment; (4) the restriction of access to natural resources and the potential replacement of diverse activities that generate food and income influence the diets of the affected families, which can also affect local food security in the long term.

Keywords: Atlantic Forest, biodiversity conservation, biological resources, food security, human ecological niche, local food resources

\section{Introduction}

Ecosystem biodiversity provides many goods and services that contribute to human well-being. The provision of natural food resources is one of those services (Blaney et al., 2009; Pimentel et al., 1997). The increase of human populations worldwide has created the challenge of meeting basic human needs for food resources while ensuring effective conservation strategies (FAO, 2014). In particular, biodiversity loss in tropical regions has often been associated with the intense use of forest environments and their resources (Faude et al., 2010).

1 Corresponding author: elainemitie@gmail.com 
Protected areas can play a key role as a mechanism for biodiversity conservation by excluding the pressures that result from the heavy use of natural resources. However, considerable biodiversity occurs within landscapes that are connected to communities' farming and fishing systems. Policy interventions that only address the protection of biodiversity without due consideration of the social and economic needs of people can have limited outcomes (Sunderland, 2011). In developing tropical countries, many human populations that live near targeted conservation areas depend on biodiversity resources, including food, for their livelihoods. This condition can result in a complex scenario where landscape conservation is sometimes combined with maintaining people's livelihoods (Allendorf, 2010; Faude et al., 2010; Nepal, 2002). The implementation of protected areas and the loss of access to natural resources by local residents or those who live in the surrounding areas has been widely discussed (e.g., Allendorf, 2010; Blaney et al., 2009; Faude et al., 2010; Nepal, 2002). Local people's welfare can be significantly negatively affected by restricting their access to the landscapes that they previously used for resource harvesting (Blaney et al., 2009; Gbetnkom, 2008).

Biodiversity in terrestrial and aquatic habitats is an important component of smallholder production systems that provide food to people who live near protected areas, which contributes to their livelihoods (FAO, 2014). "Livelihood" refers to the activities, capabilities, relationships, and assets that permeate the life of a given population (Hanazaki et al., 2013; Hesselberg \& Yaro, 2006). In turn, livelihoods influence the food security of local populations (Hanazaki et al., 2013; Hesselberg \& Yaro, 2006); that is, food security is understood as sufficient and constant food access from physical, social and economic perspectives that satisfy food needs and preferences (Barrett, 2010; Hesselberg \& Yaro, 2006). Changes in livelihoods, including legal restrictions due to biodiversity conservation strategies, can affect access to food, which modifies dietary patterns and sometimes contributes to food insecurity.

Studies of the diets of local human populations have analyzed both environmental sustainability and the components of local food security that relate to the availability of food items (DFID, 2000; Murrieta et al., 1999). In addition, the concept of the ecological niche has been widely applied as a useful tool in the analysis of the inclusion and importance of natural resources in the diets of human populations (Begossi \& Richerson, 1993; Cavallini \& Nordi, 2005; Hanazaki \& Begossi, 2000, 2003; Hardesty, 1975; MacCord \& Begossi, 2006; Silva \& Begossi, 2009). The concept of the ecological niche, when applied to human groups, is delimited by the integration of physical, biological, and cultural factors that together establish the subsistence pattern of a group of people (Hardesty, 1975). The differences among human groups with respect to an ecological niche dimension (e.g., the food dimension) can help to explain the interaction of these groups with their environments (Begossi \& Richerson, 1993; Cavallini \& Nordi, 2005; Hanazaki \& Begossi, 2000; 
Hardesty, 1975) as well as the changes that may be experienced, as reflected by mutual influences between natural resources and diet (McCune \& Kuhnlein, 2011). In addition, knowledge of the origin and significance of food resources and an understanding of local agroforestry systems can improve food security in areas that are of central importance for biodiversity conservation.

There is a need to understand the influence of biodiversity conservation policies on the relationship between local human populations and natural resources, and the implications on food security in the surroundings of a given protected area (Blaney et al., 2009; Ghimire, 1994). The present study focuses on understanding the local food systems of communities that surround a fully protected area in southern coastal Brazil and the relationship between the protected area and local food security. A former study analyzed the socioecological, sociocultural, and socioeconomic aspects of the region and identified the presence of traditional communities that surround the protected area; however, there is still a lack of knowledge concerning the relationships among livelihood activities, local resource consumption, and local food security (Foppa \& Medeiros, 2011). Traditional communities can be defined as culturally differentiated groups that recognize themselves as being culturally differentiated; they have their own forms of social organization; they occupy and use territories and natural resources as a condition for their cultural, social, religious, ancestral, and economic reproduction; and they incorporate knowledge, innovations, and practices that have been generated and transmitted by tradition (Presidency of the Republic of Brazil, 2007). Our objective was to understand the impact on the surrounding communities of the restriction of access to natural resources in an established protected area. The study first included an analysis of the local diets followed by an analysis of how access to these natural resources is related to local food security.

\section{Methods}

\section{Study area}

In Brazil, protected areas are divided into two groups: the first includes parks and seeks the full protection of ecosystems by excluding all resource extraction by humans and allowing only indirect use of the land, reserving it mainly for research and environmental education activities. Public access is not allowed in these areas, and no gathering or consumption of natural resources is allowed. The second group includes sustainable use conservation units and seeks to balance nature conservation with the planned and regulated use of some of the natural resources, such as harvesting wild foods, fishing, and the use of non-timber forest resources. Sustainable use protected areas may consist of public or private lands. Hunting is permitted only under very strict circumstances (Presidency of the Republic of Brazil, 2000). 
Acaraí State Park, which was recently created, is a fully protected area located on the coast of southern Brazil in the municipality of São Francisco do Sul, Santa Catarina State $\left(26^{\circ} 04^{\prime} 36^{\prime \prime} \mathrm{S}\right.$; $\left.48^{\circ} 38^{\prime} 17^{\prime \prime} \mathrm{W}\right)$ (Figure 1). The park was created to compensate for the installation of a steel plant with a high potential for negative environmental impacts (State of Santa Catarina, 2005). The park has an area of 6,667 hectares and aims to promote the conservation of a section of the Atlantic Forest, which has a hydric complex that is formed by freshwater and estuarine rivers, and to protect the breeding area of a number of important marine species in the Archipelago of Tamboretes (State of Santa Catarina, 2005). The ecosystems of the area can be divided into regions of mangroves, restinga (a set of physiognomically distinct marine and fluvial-marine influenced plant communities; CONAMA, 1996), dunes, and dense rain forest (IBGE, 2012). According to Brazilian legislation, state parks do not allow the direct use or extraction of natural resources (e.g., fishing and harvesting non-timber forest products). The protected area of Acaraí State Park can be accessed through the communities of Praia Grande, Tapera (São José do Acaraí), and Ervino, which represent approximately $42 \%$ of the surrounding population.

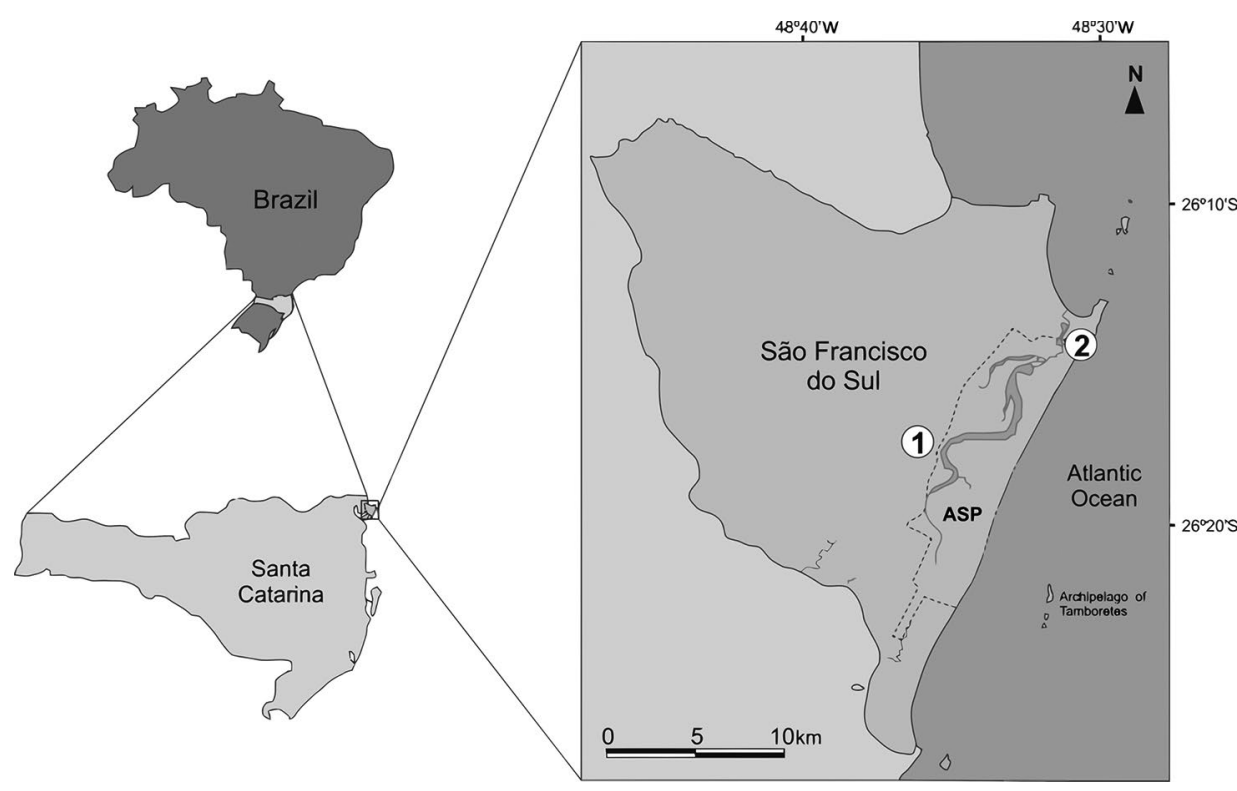

Figure 1. Location of Acaraí State Park (ASP, dotted line), São Francisco do Sul, Brazil, and the two communities, Tapera (1) and Praia Grande (2), that participated in this study

Source: Adapted from Foppa \& Medeiros (2011).

This study was conducted in the communities of Tapera and Praia Grande. Tapera includes approximately 40 households that are characterized as traditional and have diets that are at risk due to the creation and implementation of Acaraí State Park (Foppa \& Medeiros, 2011). In contrast, Praia Grande is characterized as a summer 
tourism area with a strong tourism infrastructure, which includes shops and small markets, and it has few traditional inhabitants. The community of Praia Grande has households with higher incomes compared to Tapera, evidenced by better infrastructure of households and the quality and presence of goods such as clothing, appliances, and automobiles.

Prior to data collection about food intake, we interviewed adults who have lived in these communities for at least five years, to characterize them socioeconomically. Tapera has a higher proportion of inhabitants who were born in the municipality (49\%, $n=35$, people interviewed in Tapera neighborhood), and many are from local families $(88 \%, n=17)$. People from other municipalities and from outside of the region account for $63 \%$ ( $n=107$, total people interviewed $)$ of the inhabitants. For non-natives, the average time living in these communities is 17 years, and is higher in Tapera (27 years, on average) than in Praia Grande. The average number of people per household is 2.63 (s.d. = 1.34) for Praia Grande and 2.66 (s.d. = 1.47) for Tapera.

\section{Data collection}

To assess the diversity of locally consumed biological resources, 20 households were randomly selected in each community. McCune and Kuhnlein (2011) suggest the use of a time lag during data collection to compensate for possible seasonal differences in the local items that are consumed. Thus, all of the households that were willing to cooperate were monitored during a summer (17-22 January, 2012) and winter (23-28 July, 2012) season. This study adopted the 24-hour food intake recall method (Albuquerque et al., 2010; Dufour \& Teufel, 1995) for three consecutive days during each season, excluding holidays and recess days. The repetition of food intake recall seeks to minimize fluctuations that can be derived from events that can change daily routine activities. We used a script with food items for resource consumption, and we also registered the number, age, and gender of the people in each household, as well as the origin of the foods that were consumed. A priori defined categories helped to identify the different origins of the resources that were used as food, which included purchased outside of the neighborhood; purchased within the neighborhood; purchased from local production (i.e., items purchased from a relative, neighbor, or acquaintance who lives in the same community); and cultivated or bred, donated, fished, and self-produced items (food items whose main ingredients are local biological resources). To assess food security indicators, a supplementary questionnaire was given based on a technical report on the validation of methodologies for the analysis of food security or insecurity in Brazil (UNICAMP, 2003), which is linked to national policy evaluations to avert hunger. The questionnaire investigated food vulnerability for a period of three months prior to the interviews, and included questions about the variety and quantity (sufficiency) of food. The self-reporting of household income was divided into six 
categories and placed informants on a scale of relative average income. Together with the consumption of food, family income was considered to be an important factor in predicting food insecurity (UNICAMP, 2003). The six income categories followed those defined by UNICAMP (2003): less than the minimum wage (R \$622 per month, equivalent to approximately US $\$ 352$, in January 2012), equal to one to two minimum wages, two to three minimum wages, three to five minimum wages, five to 10 , and above 10 minimum wages. Edible plant species were collected or photographed in the environments near the households (Albuquerque et al., 2010) for identification, as were economically important fish species and aquatic invertebrates. Visits to local fisheries and the donation or sale of specimens by the households also allowed for the identification of fish species. No terrestrial animals, birds, or hunted game were consumed.

\section{Data analysis}

The food dimension of the ecological niche was measured in terms of the number of citations (abundance) and the number (richness) of local biological resources that formed part of the reported meals. Niche breadth, which represents the set of resources that are exploited by an organism or a population, was also measured (Begossi \& Richerson, 1993). Thus, greater diversity may reflect greater niche breadth (generalist diet), whereas a lower diversity of consumed items reflects a narrower niche (specialist diet) (Cavallini \& Nordi, 2005; Hanazaki \& Begossi, 2003). Diversity indices were used to measure niche breadth for each community and to analyze diet overlap (Hardesty, 1975). Specifically, the standardized Levin's index (Bp) (Krebs, 1999) was obtained with ecological methodology software (Kenney \& Krebs, 2000). The standardized index reaches a maximum value if the proportion of items consumed at meals is similar, which shows a more generalist diet. Values close to zero indicate that few food items are consumed at high frequencies, and most of the items are consumed at low frequencies (more specialized diets). Also, rarefaction curves (Peroni et al., 2010) were used, and the probability of interspecific encounter (Hulbert, 1971) was calculated using the software EcoSim 7.72 (Gotelli \& Entsminger, 2012). The rarefaction curve allows the expected richness of biological resources that are consumed to be compared across the abundance of citations of consumption for different communities with different sample sizes. The probability of interspecific encounter is a simple index of diversity that shows the distribution of relative abundance of consumption of local biological resources. The overlap of food niche breadth was determined for summer and winter by calculating the percentage of niche overlap as described by Krebs (1999). 
Spearman's correlation analysis (rs) was used to verify the association between household income and food vulnerability, as well as the relationship to food quantity and variety that was assessed in the supplementary questionnaire. Spearman's correlation was used because the Shapiro-Wilk test demonstrated that neither set of data followed a normal distribution (Wincome $=0.914, p=0.011$; Wfood vulnerability $=0.546, p<0.001$ ). Statistica 7.0 (Statsoft Inc., 2004) was used for the chi-square and Shapiro-Wilk tests and Spearman's correlation.

A canonical correspondence analysis was done to understand the ordination of the households. The ordination detects patterns of variation in the data due to environmental variations. For this analysis, the data of biological resources consumed (community matrix) and socioenvironmental data (environment matrix) were used, which characterize various aspects of each community's livelihood. The data in the socioenvironmental matrix represent the explanatory variables that might influence the set of response variables; in this case, the data on abundance of locally consumed resources. This analysis reflects the influence of socioeconomic variables in the consumption of natural resources. The environmental matrix used the average number of people who share meals in the households; income (expressed in six wage classes); presence or absence of fishing activities and livestock; and habitat use, which refers to the number of habitats (i.e., home garden, crop field, vegetable garden, orchard, or mixed habitat) that were used by each household. We used the Monte Carlo test to analyze the strength of the association among the axis with the environmental variables for 999 iterations (see Legendre \& Legendre, 2012). These analyses were performed using the R package (R Development Core Team, 2012).

\section{Results}

Among the 20 selected households in each community, 18 in Tapera and 16 in Praia Grande completed the study, for a total of 34 households (six households were excluded from the sample because they did not participate in both rounds of data collection). Data were collected for 355 meals in the summer (165 in Praia Grande and 190 in Tapera) and 411 meals in the winter (188 in Praia Grande and 223 in Tapera). Altogether, 210 food items were listed in the analyzed meals. Most of the food items consumed during both of the sampled seasons, including industrial products, were purchased within the neighborhood (Figure 2). The meals of the 34 households consisted of breakfast, lunch and dinner; all of the households also had snacks between these three principal meals or even reported that at times they replaced dinner with several snacks. Within the meals, the most frequently consumed foods were coffee, bread, milk, rice, margarine, beans, beef, tomatoes, and bananas. 


\section{a) Praia Grande}

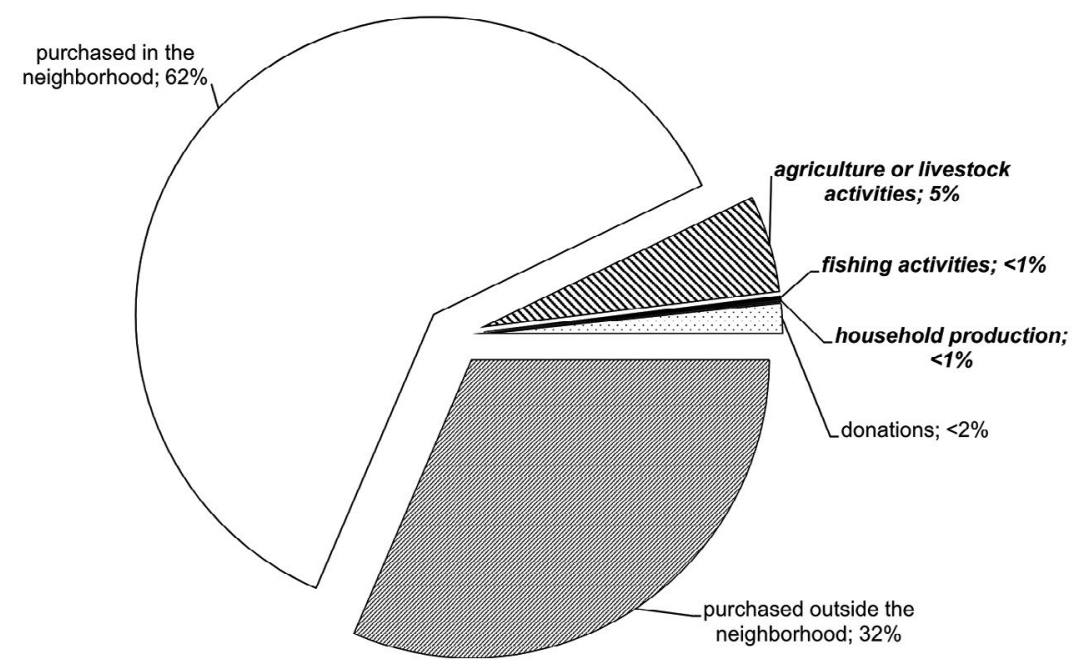

b) Tapera

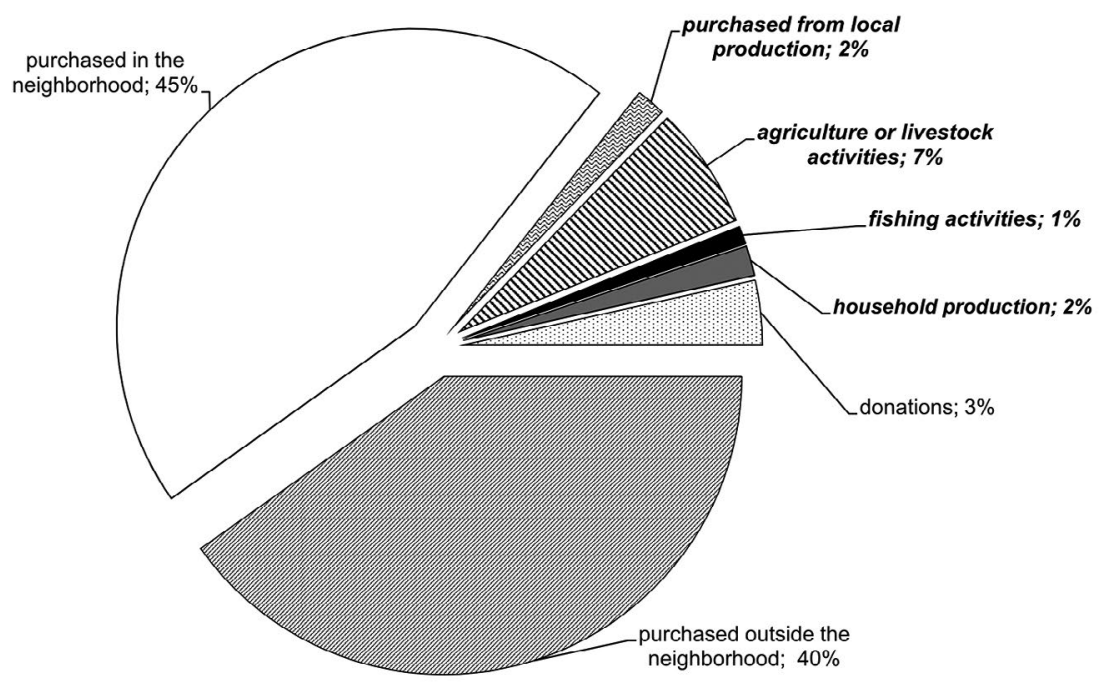

Figure 2. Resources consumed during the two studied periods (summer and winter, 2012) in the Praia Grande (a) and Tapera (b) communities

Note. Total citations for food items: Praia Grande $=2,630$, Tapera $=2,691$. The local sources of food (i.e., those that originated from livelihood activities) are shown in bold type.

The consumption of local biological resources in the region is based on foods that are cultivated, raised, or fished locally. Items that are purchased from local producers, as well as items that are produced by the households themselves, are also important in understanding the dynamics of use and dependence on local biological resources 
(Figure 2). Considering these modes of procurement, 62 different items fall into the above categories (which is equivalent to $30 \%$ of all the ingested food items). Of these, 5 are purchased from local producers, 40 are locally cultivated plants or locally raised livestock, 11 are fished, and 10 are self-produced. The Praia Grande and Tapera households consumed 32 and 50 local items, respectively. The sources of local food resources reflect the activities and livelihoods of households that interact with the environment. Farming and livestock activities that are directed at subsistence or the processing of biological resources for food are performed on the borders of the protected area, and all of the cattle are kept outside the park. Fishing is the activity that is most directly linked to the protected area because it is still performed within the park boundaries, even though it is technically an illegal activity. When considering the samples of the two seasons separately, the contribution of local resources (not purchased) to the diet of Tapera households is $22 \%$, but represents only $11 \%$ of the average Praia Grande diet. The variation in the diversity of local food resources is explicit in the rarefaction curve for these food items by season for the two communities (Figure 3). In addition, a more even distribution of the frequency of consumption of local biological resources was higher in Tapera for both seasons (probability of interspecific encounter (PIE) Tapera-summer, number of citations $(\mathrm{Nc})=68=0.936,0.906<\mathrm{CI} 95 \%<0.959$; PIE Praia Grande-summer $=0.870$; PIE Tapera-winter, Nc $=77=0.969,0.954<$ CI 95\% < 0.980; PIE Praia Grande-winter $=0.937$ ).

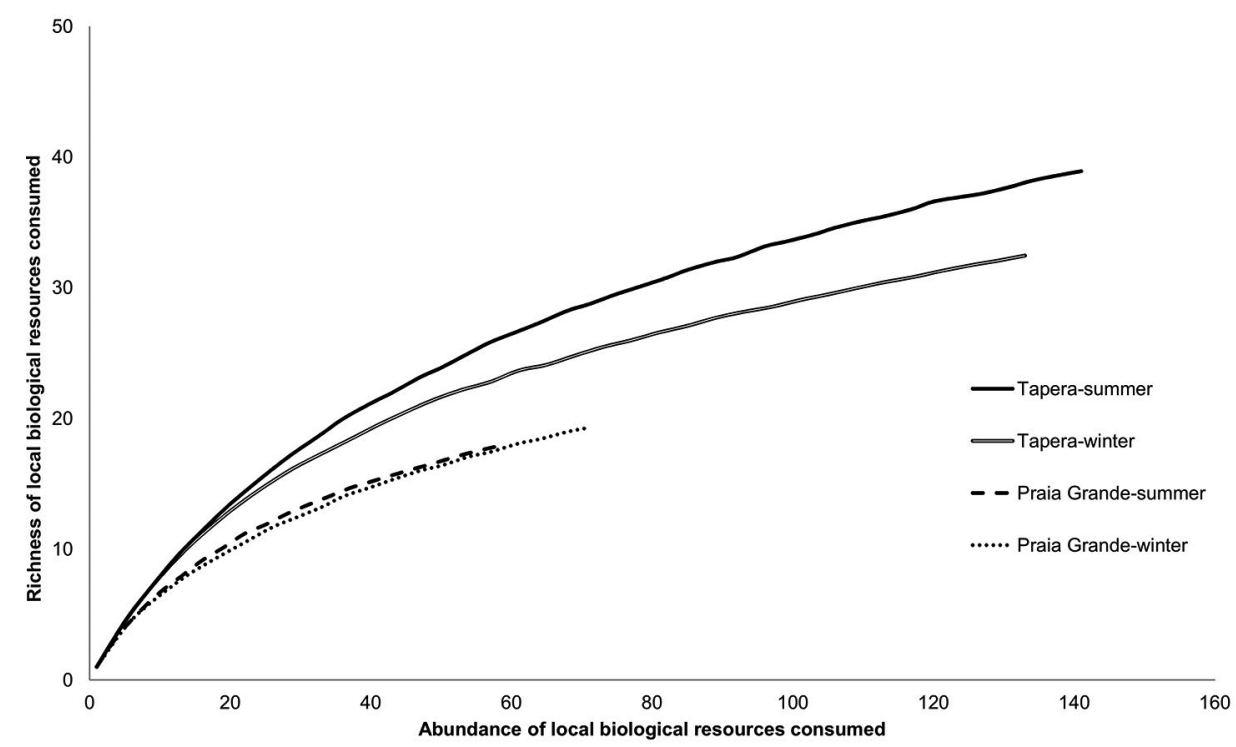

Figure 3. Rarefaction curves for the richness of local biological resources that were consumed during the studied periods (summer and winter, 2012) in Tapera and Praia Grande 
Most of the locally produced foods that are consumed are cultivated or raised (Table 1), and households in Praia Grande demand more resources of this origin, while households in Tapera have greater means of procuring local food resources.

Table 1. Modes of procuring local food resources, by community

\begin{tabular}{|l|c|c|}
\hline Modes of procuring local food resources & Praia Grande & Tapera \\
\hline Agriculture or livestock activities & 137 & 139 \\
\hline Fishing activities & 4 & 26 \\
\hline Household production & 3 & 44 \\
\hline Purchased from local production & - & 39 \\
\hline Total & 144 & 248 \\
\hline
\end{tabular}

Note. Frequency of citations for biological natural local resources consumed in 353 meals of Praia Grande (18 households) and 413 meals of Tapera (16 households).

The main items that are locally produced include cultivated plants and the byproducts of raised livestock. Among the cultivated plants, spices, such as Allium fistulosum and Petroselinum crispum (31\%, $n=316$ citations), are grown near the houses. The livestock by-products are mainly milk $(13 \%, n=316)$ and cheese $(10 \%, n=316)$. Cassava flour (Manihot esculenta), milk, cheese, and fish (Mugil liza) are produced or caught by household members or purchased locally. In Praia Grande, there were few citations for fish resources $(0.2 \%, n=2,630$ citations), and the most commonly cited fish species were Mugil curema, Menticirrhus littoralis, and Mugil liza. Mugil curema contributes the most to this community $(50 \%, n=4)$. In Tapera, the most important fish resources are Geophagus brasiliensis, Mugil liza, Centropomus undecimalis, and Micropogonias furnieri. Geophagus brasiliensis is consumed only in this community and represented $20 \%$ ( $n=20$ citations) of the fish items that were reported in the summer period. Mugil liza was a major contributor to the total fish items in Tapera during both seasons. Together, Geophagus brasiliensis and Mugil liza account for $51 \%$ ( $n=49$ citations) of the fish resources that are used for food in Tapera, and these species sell the best in the community due to local preferences. Tapera households also collect aquatic invertebrates along the beach for food (e.g., the bivalves Anomalocardia brasiliana and Donax sp. and the crustacean Emerita brasiliensis). In Tapera, fishing activities depend on direct access to the protected area. The households interviewed in this community reported that all of the consumed fish species are caught exclusively from the freshwater river inside of the protected area. All of the species cited by the households in Praia Grande are caught from marine ecosystems. 
The ecological niche for food dimension (standardized Levin's index, Table 2) shows that few local biological resources are consumed with high frequency. The households in Tapera demonstrated a preference for local resources only in the summer; therefore, the Levin index is smaller for this season than for winter. The local resources that are found within the protected area are Geophagus brasiliensis and Micropogonias furnieri. Compared to the households in Praia Grande, the households in Tapera use local resources more frequently and thus have a broader diet (see Table 2). Slightly more than half of the resources are shared between seasons.

Table 2. Ecological niche variables for the food dimension of local natural resources in the communities of Tapera and Praia Grande

\begin{tabular}{|l|l|c|c|c|}
\hline Community & Season & Levin's index (Bp) & Niche overlap (\%) & $\begin{array}{c}\text { Frequently used } \\
\text { items }(>0.05)\end{array}$ \\
\hline \multirow{2}{*}{ Praia Grande } & Summer & 0.335 & \multirow{2}{*}{53} & $6(n=19)$ \\
\cline { 2 - 3 } & Winter & 0.341 & & $3(n=20)$ \\
\hline \multirow{2}{*}{ Tapera } & Summer & 0.344 & \multirow{2}{*}{58} & $5(n=40)$ \\
\cline { 2 - 3 } & Winter & 0.445 & & $6(n=33)$ \\
\hline
\end{tabular}

Note. The amplitude of the ecological niche food dimension is measured by the standardized Levin's index (Bp).

The canonical correspondence analysis (Figure 4) showed a significant influence of the habitat use (HABUSE) and livestock activity (LVSTAC) vectors on the ordination of the households and on the distribution of abundance of local items (Table 3). The accumulated variance in the first two canonical axes is $53.6 \%$, which indicates the influence of environmental variables on the ordering of the households. The household ordering on the first axis returns groups two and five, which are influenced by the above variables. The ordering of Group $1(\mathrm{t} 2$, $\mathrm{t} 30$, and $\mathrm{t} 31)$ is clearly related to the fishing activities vector (FISHAC), and to the species Mugil liza, Micropogonias furnieri, Centropomus undecimalis, Mugil curema, and Eugerres brasilianus. This group has only the consumption of fish resources (caught inside the protected area) in common. Although not a significant vector (see Table 3), Group 1 represents the households that depend on fishing for their food security and shares the same starting position as the income vector (INCOME). Axis 2 references the arrangement of Group 4, which is made up mostly of households from Praia Grande (Figure 4). Two households in this community use more than one habitat near their homes, while the others use only the local garden for local food consumption. 


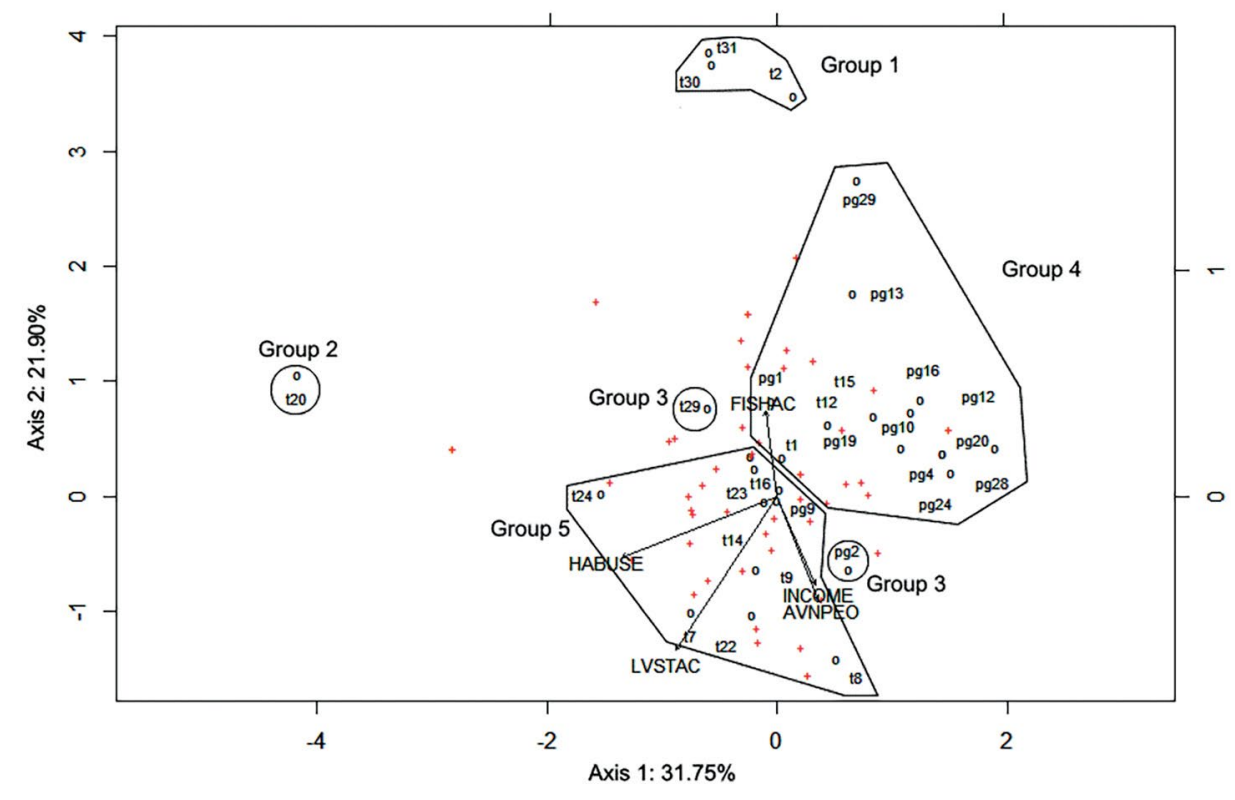

Figure 4. Scatterplot of canonical correspondence analysis; the first two axes represent the consumption of local biological resources with a socioenvironmental data matrix of 29 households from Praia Grande (pg) and Tapera (t)

Note. FISHAC = fishing activities (binary variable); LVSTAC = livestock activities (binary); HABUSE = habitat use (quantitative); INCOME = household income (ordinate); AVNPEO = average number of people present at each meal in the household (quantitative).

Table 3. Correlation coefficients between the first two axes of the canonical correspondence analysis with socioenvironmental variables, and between variables $\left(r^{2}\right)$, with probability values $(p)$ produced by Monte Carlo test after 999 iterations

\begin{tabular}{|l|c|c|c|c|}
\hline Socioenvironmental variables & Axis 1 & Axis 2 & $\mathbf{r}^{2}$ & $\boldsymbol{p}$ \\
\hline Habitat use (HABUSE) & -0.92866 & -0.37093 & 0.5422 & $0.003^{\star}$ \\
\hline Fishing activities (FISHAC) & -0.12800 & 0.99177 & 0.1433 & 0.384 \\
\hline Livestock activities (LVSTAC) & -0.54399 & -0.83909 & 0.6635 & $0.001^{*}$ \\
\hline Income classes (INCOME) & 0.40065 & -0.91623 & 0.1789 & 0.265 \\
\hline Average number of people (AVNPEO) & 0.33859 & -0.94093 & 0.2386 & 0.142 \\
\hline
\end{tabular}

Note. Values marked with * are significant after repetitions.

More than three-quarters of the households thought that their food was varied and sufficient $(76 \%, n=34$ households). There is a positive association between low-income status and household food vulnerability $(\mathrm{rs}=0.508, p=0.002)$. In Tapera, $17 \%(n=18)$ of the households reported that they frequently did not have enough to eat, which was always for economic reasons; $67 \%$ of the households in 
this community earn less than twice the minimum monthly wage. The minimum wage was insufficient to cover basic expenditures for food and housing; according to DIEESE (2016) in 2012, the minimum wage should be more than three times this value. In Praia Grande, 6\% $(n=16)$ felt that food was scarce. In the Praia Grande community, $75 \%$ of households earn at least three times the minimum monthly wage. Vegetables, meat, and children's food were the items reported as frequently missing from the basic diet in Tapera. In Praia Grande, canned foods, sausages, and dairy were reported as missing. The criteria for choosing food items included preference ( $41 \%, n=5,321$ citations), followed by no criterion $(24 \%)$, and price $(20 \%)$. The latter criterion had a higher influence in Tapera $(36 \%, n=2,691$ citations). Individual preference accounted for $52 \%(n=2,630)$ of the occurrences in Praia Grande. Finally, in Tapera there was a preference to buy locally produced items and to consume food that was produced by the household.

\section{Discussion}

Analyses based on ecological concepts can reveal spatial and temporal differences in the use of natural resources (Begossi \& Richerson, 1993; Cavallini \& Nordi, 2005; Hanazaki \& Begossi, 2000). In human populations, household income also influences availability and access to resources (Begossi \& Richerson, 1993; Hanazaki \& Begossi, 2000; MacCord \& Begossi, 2006; Nascimento et al., 2010; Silva $\&$ Begossi, 2009). Income was not significant within the studied communities; however, it is important to understand the context of the lower amplitude of food resources for households in Praia Grande. The Praia Grande households are in an urban environment, which allows them to consume more purchased items and makes their relationship to subsistence more economical than ecological (Nascimento et al., 2010; Reyes-García et al., 2005). The Tapera households experience greater economic fluctuation due to fewer income-generating opportunities (Foppa \& Medeiros, 2011), which in turn increases their consumption of a variety of local biological resources, including those that are locally produced, resulting in a greater niche breadth.

Understanding the differences in the diets among the communities also improves the understanding of the relationship between humans and their environments (Begossi \& Richerson, 1993; Cavallini \& Nordi, 2005; Hanazaki \& Begossi, 2000; McCune \& Kuhnlein, 2011). The livelihoods of people in Praia Grande include food cultivation (such as home gardens, crops, orchards, and vegetable gardens) and livestock-rearing practices that, together with higher incomes, reduce their direct dependence on their environmental surroundings, including resources within the park boundaries. In Tapera, there is a clear influence of local biological resources on the observed diets because diverse farming habitats and livestock, fishing, and food production activities contribute to the local system of subsistence. A strong 
interaction with the local environment leads to a greater richness of consumed local resources and a greater amplitude of the ecological niche food dimension for these items. The greater niche breadth that was observed in winter reflects the temporal generalization in the diets of the Tapera households. The low percentage of niche overlap in Tapera means that environmental changes during the year help to define the consumption of local items. A lower richness of consumption during winter may reflect a preference for foods that are found only during summer, which favors the increased intake of other local resources when the preferred item is absent (Begossi \& Richerson, 1993; Nascimento et al., 2010). The preferred local resources include two species of fish that are caught in the freshwater river of the protected area: Geophagus brasiliensis and Micropogonias furnieri. Fishing for one of them (Geophagus brasiliensis) is considered to be a collective activity that is culturally important (Foppa \& Medeiros, 2011), and it is highly dependent on the protected area environment.

The influence of local livelihoods on the use of resources highlights the direct dependence on the natural resources in each community (Begossi \& Richerson, 1993; Salafsky \& Wollenberg, 2000); however, we observed a predominance of non-locally produced items. The process of urbanization, and the reported decrease in activities such as small-scale farming and artisanal fishing may strengthen the inclusion of non-local products in the diet. Similar factors have also been noted in other studies (MacCord \& Begossi, 2006; Murrieta et al., 1999; Silva \& Begossi, 2009). However, some Tapera households share a strong relationship with the territory upon which they depend for their livelihood. Although only a few households are dependent on the protected area, fishing helps to build the local food scene because it is an important means of obtaining food. According to Godoy et al. (2005), few local human populations depend exclusively on biodiversity resources, and most have a more direct relationship with cultivated food and commercialized products, which is the case for the communities around Acaraí State Park. However, the creation of a protected area as a strategy for biological conservation can shift the degradation of environments and biodiversity to other unprotected areas because areas for cultivation and livestock are needed to offset the use of natural resources for subsistence and food (Godoy et al., 2005; Vadez et al., 2004).

Especially for Tapera families, who depend more on the use of resources and the environment, changes in access to resources could have major consequences. Increased urbanization and the restrictions imposed by environmental laws that limit the use of natural resources can contribute markedly to a progressive dependency on market products (as observed by Hanazaki \& Begossi, 2000; MacCord \& Begossi, 2006; Murrieta et al., 1999; Silva \& Begossi, 2009). This can occur as a replacement strategy for fish species that are consumed and come from within the park, which could result in the gradual abandonment of traditional livelihood activities that lead to a decrease in food self-sufficiency (MacCord \& Begossi, 2006; Murrieta 
et al., 1999). Changes in dietary patterns can affect nutritional quality because new food items that are added do not necessarily replace the range of foodstuffs that were consumed previously (Silva \& Begossi, 2009). Although there is a positive relationship between income and the consumption of calories in a diet (Fitzgerald et al., 1992), purchased commodities can contain fewer nutrients per kilogram consumed than the wild-captured foods that were formerly consumed, with potential negative health outcomes.

In other ecosystems of the Atlantic Forest and Amazonia, limited access to and use of natural resources interferes with the livelihoods and diets of local human populations (Hanazaki \& Begossi, 2000, 2003; MacCord \& Begossi, 2006; Murrieta et al., 1999; Silva \& Begossi, 2009). Such changes can be dangerous because they lead to the abandonment of food systems based on resources from the local environments, and threaten the knowledge dynamics that are associated with these systems (Kuhnlein \& Receveur, 1996). We observed there are stronger links to resources from the protected area in the community with livelihoods that interact more with the local environment (Tapera). However, this link was mostly related to fishing resources for a few households, which relates to the importance of managed habitats as sources of local food resources.

Ecosystems that are conserved by protected areas can be co-managed for better conservation outcomes and still deliver significant resources to local populations (Pimentel et al., 1997; Sunderland, 2011). However, local food security may be greatly affected if the process of establishing and managing a protected area severely limits access to subsistence sources that are related to natural resources and does not include proper planning for subsistence alternatives. Areas such as forests and associated ecosystems are important to food security because they are a source of resources and underpin an environment that is useful for sustainable agriculture (Sunderland, 2011).

In other developing countries, such as Thailand and Madagascar, the restriction of access to natural resources has had an unexpected result in terms of environmental conservation (Ghimire, 1994; Neef et al., 2003). According to Ghimire (1994) and Neef et al. (2003), the degradation of ecosystems and the loss of biodiversity continue at alarming rates in major parks in these countries because the conflicts between environmental protection policies and local human livelihoods have not been resolved cooperatively. The implementation of restrictive policies on access to biodiversity resources can ultimately lead local populations to seek alternatives to ensure their food security and livelihoods, thus increasing the pressure on the environments that surround the created protected areas (Ghimire, 1994; Neef et al., 2003). The creation of a protected area implies behavioral changes in the surrounding communities (Baird \& Leslie, 2013). In the case of Acaraí State Park, the restrictions have the potential to diversify the livelihoods of the families that continue fishing as a source of food (who were formerly dependent on the park area). In a park in 
Tanzania, Baird \& Leslie (2013) found that the closer communities are to a park, the more diverse the livelihoods will be because the communities adapt to the changes that are promoted by the protected area. The diversification of livelihoods happens in response to the disturbances generated by the establishment of a protected area and the constraints and opportunities that arise over time (e.g., nongovernmental organization actions, tourism, expansion of protected area boundaries).

An alternative that has been explicitly considered by the managers of Acaraí State Park is the potential of community-based tourism to provide a source of employment and income. This is one of the public-use activities that aims to reduce the impact on natural resources, although it is not without its own set of impacts. Other alternatives may consider the proper use of the buffer zone, which is the zone around the protected area. An important point is that in the buffer zone of the park, commercial fishing (artisanal, practiced by professional fisherman using small vessels and in a family economy system; or industrial, practiced using small, medium, or large vessels for commercial purposes) is permitted, which may have an impact on the population of the fish fauna in freshwater environments inside the protected area.

Food insecurity in the studied area can be more intense for households that use local resources as food, as well as for the households that indicated vulnerability to food insecurity. Thus, it is worth emphasizing the importance of the multiple strategies that have been adopted by the households to ensure their livelihoods. For the households whose subsistence and livelihoods are linked even partially to local biological resources, the displacement of diverse activities that generate food and income can increase vulnerability and the potential for food insecurity (Foppa $\&$ Medeiros, 2011; Hanazaki et al., 2013; Hesselberg \& Yaro, 2006) by decreasing the capacity to cope with social, economic, and environmental crises (Barrett, 2010; Hanazaki et al., 2013).

\section{Conclusions}

The influence of the different uses of habitats and livelihood activities shows the importance of strategies that comprise local ways of life in obtaining food and, consequently, in local food security. The differences in the amplitude of the ecological niche of the analyzed families have origins in the availability of and access to natural resources, the acquisition of industrialized products, economic activities, and socioeconomic differences. Ecological concepts help to support an understanding of the relationships among the people in their environment and allow for the differentiation of dietary patterns between the studied communities. 
In the context of Brazilian protected areas and the restrictions that have been imposed within Acaraí State Park, joint actions between the park managers and the households that depend on subsistence resources could focus on use of the buffer zone as a source of livelihood resources. Local food systems were shown to exist in this study, confirming the connectivity between the protected area and productive systems and their significance to food security and biodiversity conservation. For the studied communities, fishing is important to the food security of some of the households that surround the protected area. Fish are the most influential resource in relation to the people and the protected area, which results in an increase in the use of resources in the region. A formal agreement with the households that depend on the environment and subsistence resources can ensure the continuity of these activities within the law.

It is necessary to monitor and control commercial fishing landings and monitor ichthyofauna in the interior water bodies and buffer zone, in order to evaluate the influence of commercial fishing inside the protected area on the stocks that local families depend on for subsistence. Studies in protected marine areas in Australia and the Mediterranean have shown that including local fisherman in coordinated management decisions about these areas demonstrates to them the costs and benefits of conservation and creates a network that can help to balance the trade-offs, which is a key to connecting the conservation of biodiversity and fishing goals (Weigel et al., 2014). Similar strategies could be adopted in Acaraí State Park. In addition, a more thorough evaluation is necessary to better understand the possibilities of creating and operating tourist activities as an alternative income source while maintaining the objectives of the fully protected conservation area.

Considering the integrity of the communities near Acaraí State Park, and the influence of conservation actions and use of environmental space in this region, it is imperative to regulate activities that will allow for the maintenance of the livelihoods of local human populations and, at the same time, clarify the rights of these people, which will create autonomy in their decisions related to using natural resources. The surrounding communities can benefit from this protected area as long as conservation efforts avoid drastic changes that undermine household food security.

\section{References}

Albuquerque, U. P., Lucena, R. F. P., \& Alencar, N. L. (2010). Métodos e técnicas para a coleta de dados etnobiológicos. In U. P. Albuquerque, R. F. P. Lucena, $\&$ L. V. F. C. C. Cunha (Eds.), Métodos e técnicas na pesquisa etnobiológica e etnoecológica (pp. 41-64). Recife, Brazil: NUPEEA. 
Allendorf, T. D. (2010). A framework for the park-people relationship: Insights from protected areas in Nepal and Myanmar. International Journal of Sustainable Development \& World Ecology, 17, 417-422. doi.org/10.1080/ 13504501003788180

Baird, T. D., \& Leslie, P. W. (2013). Conservation as disturbance: Upheaval and livelihood diversification near Tarangire National Park, northern Tanzania. Global Environmental Change, 23, 1131-1141. doi.org/10.1016/j. gloenvcha.2013.05.002

Barrett, C. B. (2010). Measuring food insecurity. Science, 327, 825-828. doi.org/ $10.1126 /$ science. 1182768

Begossi, A., \& Richerson, P. J. (1993). Biodiversity, family income and ecological niche: A study on the consumption of animal foods on Búzios Island (Brazil). Ecology of Food and Nutrition, 30, 51-61. doi.org/10.1080/03670244.1993.99 91322

Blaney, S., Beaudry, M., \& Latham, M. (2009). Contribution of natural resources to nutritional status in a protected area of Gabon. Food and Nutrition Bulletin, 30, 49-62. doi.org/10.1177/156482650903000105

Cavallini, M. M., \& Nordi, N. (2005). Ecological niche of family farmers in southern Minas Gerais state (Brazil). Brazilian Journal of Biology, 65, 61-66. doi.org/10.1590/S1519-69842005000100009

CONAMA. (1996). Resoluçáo n. 07. De 23 de Julho de 1996. National Environmental Council (Brazil). Retrieved from www.mma.gov.br/port/ conama/res/res96/res0796.html

DFID (United Kingdom Government Department for International Development). (2000). Sustainable livelihoods guidance sheets. London: DFID.

DIEESE (Inter-Union Department of Statistics and Socio-Economic Studies, Brazil). (2016). Cesta básica nacional. Salário mínimo nominal e necessário. Retrieved from www.dieese.org.br/analisecestabasica/salarioMinimo.html

Dufour, D. L., \& Teufel, N. I. (1995). Minimum data sets for the description of diet and measurement of food intake and nutritional status. In E. F. Moran (Ed.), The comparative analysis of human societies (pp. 87-128). Boulder, CO: Lynne Rienner.

FAO (Food and Agriculture Organization of the United Nations). (2014). Protected areas, people and food security. An FAO contribution to the World Parks Congress. Sydney: FAO. Retrieved from www.fao.org/3/a-i4198e.pdf 
Faude, U., Feilhauer, H., \& Schmidtlein, S. (2010). Estimating the impact of forest use on biodiversity in protected areas of developing tropical regions. Erdkunde, 64, 47-56. doi.org/10.3112/erdkunde.2010.01.04

Fitzgerald, S., Gibson, R. S., Portocarrero, L., Quan De Serrano, L., Vasquez, A., Zepeda, E., ... Solomons, N. W. (1992). Food consumption patterns and dietary diversity of pregnant women living in a peri-urban area of Guatemala city. Ecology of Food and Nutrition, 27, 4-45. doi.org/10.1080/03670244.199 2.9991221

Foppa, C. C., \& Medeiros, R. P. (2011). Nosso Acaraí: Dinâmica socioecológica e relaçóes territoriais das populaçóes tradicionais da área de entorno do Rio Acarai, municipio de Sáo Francisco (SC). Technical report presented to the records of the Public Civil Action, number 061.07.009145-6. Ministério Público Estadual/ FATMA. Itajaí, Brazil: UNIVALI.

Gbetnkom, D. (2008). Forest depletion and food security of poor rural populations in Africa: Evidence from Cameroon. Journal of African Economies, 18, 261-286. doi.org/10.1093/jae/ejn012

Ghimire, K. B. (1994). Parks and people: Livelihood issues in national parks management in Thailand and Madagascar. Development and Change, 25, 195-229. doi.org/10.1111/j.1467-7660.1994.tb00514.x

Godoy, R., Reyes-García, V., Byron, E., Leonard, W. R., \& Vadez, V. (2005). Economies on the well-being of indigenous peoples and on their use of renewable natural resources. Annual Review of Anthropology, 34, 121-138. doi.org/10.1146/annurev.anthro.34.081804.120412

Gotelli, N. J., \& Entsminger, G. L. (2012). EcoSim: Null models software for ecology (Version 7.72). Acquired Intelligence Inc. \& Kesey-Bear. Retrieved from www.uvm.edu/ ngotelli/EcoSim/EcoSim.html

Hanazaki, N., \& Begossi, A. (2000). Fishing and niche dimension for food consumption of Caiçaras from Ponta do Almada (Brazil). Human Ecology Review, 7, 52-59.

Hanazaki, N., \& Begossi, A. (2003). Does fish still matter? Changes in the diet of two Brazilian fishery communities. Ecology of Food and Nutrition, 42, 279-301. doi.org/10.1080/03670240390229643

Hanazaki, N., Berkes, F., Seixas, C. S., \& Peroni, N. (2013). Livelihood diversity, food security and resilience among the Caiçara of coastal Brazil. Human Ecology, 41, 153-164. doi.org/10.1007/s10745-012-9553-9 
Hardesty, D. L. (1975). The niche concept: Suggestions for its use in human ecology. Human Ecology, 3, 71-85. doi.org/10.1007/BF01552263

Hesselberg, J., \& Yaro, J. A. (2006). An assessment of the extent and causes of food insecurity in northern Ghana using a livelihood vulnerability framework. GeoJournal, 67, 41-55. doi.org/10.1007/s10708-006-9007-2

Hulbert, S. H. (1971). The non-concept of species diversity: A critique and alternative parameters. Ecology, 2, 577-586. doi.org/10.2307/1934145

IBGE (Brazilian Institute of Geography and Statistics). (2012). Manuais técnicos em geociências: Manual técnico da vegetação Brasileira (2nd ed.). Rio de Janeiro: IBGE. Retrieved from www.terrabrasilis.org.br/ecotecadigital/pdf/manualtecnico-da-vegetacao-brasileira.pdf

Kenney, A. J., \& Krebs, C. J. (2000). Programs for ecological methodology (2nd ed.). Vancouver: Department of Zoology, University of British Columbia.

Krebs, C. J. (1999). Ecological methodology (2nd ed.). Amsterdam: Addison Wesley.

Kuhnlein, H. V., \& Receveur, O. (1996). Dietary changes and traditional food systems of indigenous peoples. Annual Review of Nutrition, 16, 417-442. doi.org/10.1146/annurev.nu.16.070196.002221

Legendre, P., \& Legendre, L. (2012). Numerical ecology (3rd ed.). Oxford: Elsevier.

MacCord, P. L., \& Begossi, A. (2006). Dietary changes over time in a Caiçara community from the Brazilian Atlantic Forest. Ecology and Society, 11(2), 38. doi.org/10.5751/ES-01873-110238

McCune, L. M., \& Kuhnlein, H. V. (2011). Assessments of indigenous peoples' traditional food and nutrition systems. In E. N. Anderson, D. Pearsall, E. Hunn, \& N. Turner (Eds.), Ethnobiology (pp. 249-265). Hoboken, NJ: Wiley-Blackwell. doi.org/10.1002/9781118015872.ch15

Murrieta, R. S. S., Dufour, A. L., \& Siqueira, A. (1999). Food consumption and subsistence in three Caboclo populations on Marajó Island, Amazonia, Brazil. Human Ecology, 27, 455-475. doi.org/10.1023/A:1018779624490

Nascimento, A. P. B., Ferreira, M. L., \& Molina, S. M. G. (2010). Ecological niche theory: Non-traditional urban and rural human populations. Journal of Human Ecology, 32, 175-182.

Neef, A., Onchan, T., \& Schwarzmeier, R. (2003). Access to natural resources in mainland southeast Asia and implications for sustaining rural livelihoods: The case of Thailand. Quarterly Journal of International Agriculture, 42, 33293350 . 
Nepal, S. K. (2002). Involving indigenous peoples in protected area management: Comparative perspectives from Nepal, Thailand, and China. Environmental Management, 30, 748-763. doi.org/10.1007/s00267-002-2710-y

Peroni, N., Araujo, H. F. P., \& Hanazaki, N. (2010). Métodos ecológicos na investigaçâo etnobotânica e etnobiológica: $\mathrm{O}$ uso de medidas de diversidade e estimadores de riqueza. In U. P. Albuquerque, R. F. P. Lucena, \& L. V. F. C. C. Cunha (Eds.), Métodos e técnicas na pesquisa etnobiológica e etnoecológica (pp. 255-276). Recife, Brazil: NUPEEA.

Pimentel, D., McNair, M., Buck, L., Pimentel, M., \& Kamil, J. (1997). The value of forests to world food security. Human Ecology, 25, 91-120. doi.org/ 10.1023/A:1021987920278

Presidency of the Republic of Brazil. (2000). Lei n. 9.985, de 18 de Julho de 2000. Retrieved from www.planalto.gov.br/ccivil_03/Leis/L9985.htm

Presidency of the Republic of Brazil. (2007). Decreto n. 6.040, de 7 de Fevereiro de 2007. Retrieved from www.planalto.gov.br/ccivil_03/_ato2007-2010/2007/ decreto/d6040.htm

R Development Core Team. (2012). R: A language and environment for statistical computing. R Foundation for Statistical Computing. Retrieved from www.R-project.org/

Reyes-García, V., Vadez, V., Byron, E., Apaza, L., Leonard, W. R., Pérez, E., \& Wilkie, D. (2005). Market economy and the loss of folk knowledge of plant uses: Estimates from the Tsimane' of the Bolivian Amazon. Current Anthropology, 46, 651-656. doi.org/10.1086/432777

Salafsky, N., \& Wollenberg, E. (2000). Linking livelihoods and conservation: A conceptual framework and scale for assessing the integration of human needs and biodiversity. World Development, 28, 1421-1438. doi.org/10.1016/S0305750X(00)00031-0

Silva, A. L., \& Begossi, A. (2009). Biodiversity, food consumption and ecological niche dimension: A study case of the riverine populations from the Rio Negro, Amazonia, Brazil. Environment, Development and Sustainability, 11, 489-507. doi.org/10.1007/s10668-007-9126-z

State of Santa Catarina. (2005). Decreto Estadual n. 3.517, de 23 de Setembro de 2005. Retrieved from www.fatma.sc.gov.br/images/stories/educação_\%20 ambiental/decreto_3517_parque_acara.pdf

Statsoft Inc. (2004). Statistica $7.0^{\circ}$. Retrieved from www.statsoft.com 
Sunderland, T. C. H. (2011). Food security: Why is biodiversity important? International Forestry Review, 13, 265-274. doi.org/10.1505/ 146554811798293908

UNICAMP (University of Campinas). (2003). Segurança alimentar no Brasil: Validação de metodologia para acompanhamento e avaliação. Relatório técnico de acompanhamento e avaliação da segurança alimentar de famílias brasileiras: Validação de metodologia e de instrumento de coleta de informação. Ministério da Saúde/OPAS/FAPESP. Campinas, Brazil: UNICAMP.

Vadez, V., Reyes-García, V., Godoy, R. A., Apaza, V. L., Byron, E., Huanca, T., ... Wilkie, D. (2004). Brief communication: Does integration to the market threaten agricultural diversity? Panel and cross-sectional data from a horticulturalforaging society in the Bolivian Amazon. Human Ecology, 32, 635-646. doi.org/ $10.1007 / s 10745-004-6100-3$

Weigel, J., Mannle, K. O., Bennett, N. J., Carter, E., Westlund, L., Burgener, V., ... Hellman, A. (2014). Marine protected areas and fisheries: Bridging the divide. Aquatic Conservation: Marine and Freshwater Ecosystems, 24, 199-215. doi.org/ $10.1002 /$ aqc. 2514 
This text is taken from Human Ecology Review, Volume 23, Number 1, 2017, published 2017 by ANU Press, The Australian National University, Canberra, Australia.

dx.doi.org/10.22459/HER.23.01.2017.06 